\title{
Anti-Hyperlipidemia and Anti-obesity Properties of Garcinia atroviridis and Camellia sinensis Extracts in High-Fat Diet Mice ${ }^{\dagger}$
}

\author{
Anawat KONGCHIAN ${ }^{1}$, Narissara KEAWBOONLERT ${ }^{2}$, \\ Thanchanok BOONRAK ${ }^{2}$, Sarai LOOKYEE ${ }^{2}$, Krittiyaporn BUASRI ${ }^{2}$, \\ Nassaree SURONGKUL ${ }^{2}$ and Jitbanjong TANGPONG ${ }^{1,2,3, *}$
}

\author{
${ }^{I}$ Division of Biomedical Sciences, School of Allied Health Sciences, Walailak University, \\ Nakhon Si Thammarat 80161, Thailand \\ ${ }^{2}$ Division of Medical Technology, School of Allied Health Sciences, Walailak University, \\ Nakhon Si Thammarat 80161, Thailand \\ ${ }^{3}$ Research Excellence Center for Innovation and Health Products (RECIHP), Walailak University, \\ Nakhon Si Thammarat 80161, Thailand
}

("Corresponding author's e-mail: rjitbanj@wu.ac.th)

Received: 22 April 2019, Revised: 5 July 2019, Accepted: 19 August 2019

\begin{abstract}
Hyperlipidemia and obesity are risk factors that contribute to cardiovascular diseases, diabetes, and hypertension among the world's population. The present study aimed to investigate the effects of green tea (Camellia sinesis) and Garcinia (Garcinia atroviridis) extracts in high-fat diet mice. The mice were fed with a high-fat diet and orally administrated extracts once daily. The extracts displayed a significant decrease in body weight, triglyceride, low-density lipoprotein (LDL) cholesterol, total cholesterol, atherosclerosis index (AI), and glucose levels in blood. High-density lipoprotein (HDL) cholesterol significantly increased. Treatment with the extracts reduced the lipid peroxidation marker, malondialdehyde (MDA), and indicated the pathohistology of lower fat cells deposited in liver tissues. In in vitro studies, the extracts have been identified to be capable of inhibiting the activity of amylase and glucoside enzymes and scavenging free radicals. Moreover, both green tea and Garcinia extracts showed non-toxicity as presented by the activity of aspartate aminotransferase (AST), alanine aminotransferase (ALT), and blood urea nitrogen (BUN). In conclusion, the pathogenic factors involved in atherosclerosis were reduced by green tea and Garcinia extracts, and both extracts could be useful for better prevention and treatment of atherosclerosis and cardiovascular diseases.
\end{abstract}

Keywords: Anti-hyperlipidemia, Anti-glycemic, Atherosclerosis, Camellia sinensis, Garcinia atroviridis, High-fat diet mice, Cardiovascular disease

\section{Introduction}

Hyperlipidemia and obesity are defined as abnormal or excessive cholesterol in blood and fat accumulation in tissues, which increase the risk of cardiovascular disease and stroke, the major cause of morbidity and mortality of the global population. Low-density lipoprotein (LDL) cholesterol is 1 of the most important atherogenic lipoprotein, and oxidation of LDL to Ox-LDL indicates the 1st step of atherosclerosis in cardiovascular diseases [1]. Malondialdehyde is well-known as the indicator of lipoperoxidation and is a sign of increased oxidative stress. The high-fat diet studies in animals, such as a

\footnotetext{
${ }^{\dagger}$ Presented at the International Conferences on Biomedical Sciences and Medical Technology 2019: June 20 - 21, 2019
} 
diet with a high consumption of saturated fat and cholesterol, can influence the prevalence of metabolic syndrome, which increases the risk of developing type 2 diabetes and cardiovascular diseases. Hyperlipidemia and hyperglycemia affect antioxidant status and related to increased oxidative damage. The usage of natural products from plant origin in treating hyperlipidemia can reduce blood lipids [2,3]. It is well-known that lipid-lowering drugs have an adverse effect to long-term consumption in liver and muscle toxicity [4].

Green tea (Camellia sinensis) is a famous and widely consumed beverage worldwide. Green tea has been shown to have significant health-promoting effects. It contains an abundant source of polyphenolic flavonoid known as catechin. There are some major isomers of this compound, which are catechingallate (CG), gallocatechingallate (GCG), epicatechingallate (ECG), epigallocatechin, and epigallocatechingallate (EGCG). Normally, $10-20 \%$ of the catechins in green tea leaves are epigallocatechin and EGCG [5]. Drinking green tea can induce antioxidant [6], antiviral [7], antiplaque forming [8], and anticancer [9] activities, as well as decrease blood pressure [10], blood glucose levels, and body weight [11]. Lipid metabolism studies in animals have found that green tea reduces triglyceride and total cholesterol concentrations [12] and inhibits hepatic and visceral fat accumulation [13]. Recent studies suggest that EGCG reduces the development and progress of various diseases, such as cancer and cardiovascular diseases [14,15].

Garcinia (Garcinia atroviridis) is a large rainforest tree that is mostly found in the southern part of Thailand and the northern part of Malaysia. Garcinia has been used in healthy diets for centuries in many areas of tropical Asia. Sun-dried slices of the fruits are usually used as a seasoning in curries or soups to give a sour taste. Garcinia contains tartaric, citric, and ascorbic acid, which have antioxidant activities and play a role in anti-microbial, anti-tumor, and anti-inflammatory activities [16]. However, the most important bioactive compound is hydroxyl citric acid (HCA) [17]. This compound is a competitive inhibitor of adenosine triphosphate citrate lyase [18]. The action of HCA exerts as an inhibitor of fatty acid synthesis [19]. HCA is usually used as a weight loss supplement either alone or in combination with other supplements [20]. Moreover, consumption of HCA can promote weight loss and reduce fat accumulation $[21,22]$.

The present study aimed to investigate the effects of green tea and Garcinia aqueous extracts on anti-glycemic in vitro study, anti-hyperlipidemic and atherosclerosis index, and glucose in high-fat diet mice (HFD). It is hypothesized that green tea and Garcinia will attenuate the development of obesity and can be used in potential diets for health promotion.

\section{Materials and methods}

\section{Sample preparation}

Garcinia fruits were purchased from a local supplier in Nakhon Si Thammarat, Thailand. The fruits were prepared by air-drying, cutting them into small pieces (100 g), and using heat pressure water extraction $(800 \mathrm{ml})$. Then, the extract was filtrated by using 0.45 micron filter. The resultant solution was freeze-dried using lyophilizer, and then the extract powder was kept in an air-tight container and stored in a freezer $\left(-20^{\circ} \mathrm{C}\right)$ until further analysis. Green tea leaves were purchased from Chiang Rai, Thailand. Green tea leaves were prepared by air-drying, grinding them into small pieces (100 g), and using heat pressure water extraction $(800 \mathrm{ml})$. Then the extract was filtrated using 0.45 micron filter. The resultant solution was freeze-dried using lyophilizer, and then the extract powder was kept in an air-tight container and stored in a freezer $\left(-20^{\circ} \mathrm{C}\right)$ until further analysis.

\section{Determination of total phenolic content}

The total phenolic content was determined using the Folin-Ciocalteu reagent followed by a previous method [23] with a minor modification. Briefly, $10 \mu$ diluted extract solution was mixed with $10 \mu \mathrm{l}$ of tenfold diluted Folin-Ciocalteu's phenol reagent and allowed to react for $5 \mathrm{~min}$. Then $100 \mu \mathrm{l}$ of $7.5 \%$ sodium carbonate $\left(\mathrm{Na}_{2} \mathrm{CO}_{3}\right)$ solution was added, and the final volume was increased to $200 \mu \mathrm{l}$ by adding deionized water. After the reaction for $15 \mathrm{~min}$ at room temperature, the absorbance at $765 \mathrm{~nm}$ was 
determined. The calibration curve was obtained with gallic acid, and the results were expressed as mg of gallic acid equivalents per gram of dry weight (mg GAE/g dry weight).

\section{Determination of free radical scavenging activity on DPPH}

The antioxidant activity of the extracts was determined in terms of radical scavenging ability using the stable radical DPPH. The protocol was modified from the method of Blios (1958) [24]. Briefly, $50 \mu 1$ of prepared sample extracts at various concentrations was added to $200 \mu \mathrm{l}$ of a $100 \mu \mathrm{M}$ ethanolic solution of DPPH and allowed to stand for $20 \mathrm{~min}$ at room temperature. The absorbance of the sample was measured at $517 \mathrm{~nm}$. Radical scavenging activity was expressed as the inhibition percentage of free radical by the sample and was calculated using the formula $\left[1-\left(\mathrm{A}_{\text {sample }} / \mathrm{A}_{\text {control }}\right)\right] \times 100$, where $\mathrm{A}_{\text {sample }}$ is the absorbance of the extracts or standards mixed with DPPH and $\mathrm{A}_{\text {control }}$ is the absorbance of the DW mixed with DPPH.

\section{Determination of free radical scavenging activity on ABTS}

The total antioxidant activity of the samples was measured by ABTS radical cation decolorization assay and was performed with a slight modification from the method of Re et al. [25]. ABTS was produced by reacting $7 \mathrm{mM}$ ABTS aqueous solution with $2.4 \mathrm{mM}$ potassium persulfate in the dark for 12 $-16 \mathrm{~h}$ at $4{ }^{\circ} \mathrm{C}$. Prior to assay, this solution was diluted in DW to give an absorbance at $734 \mathrm{~nm}$ of $0.700 \pm$ 0.02 . Free radical scavenging activity was performed by adding $20 \mu \mathrm{l}$ of the extracts or standard solution and mixed with $180 \mu \mathrm{l}$ of the working ABTS cation radical reagent. The absorbance was measured at 734 $\mathrm{nm}$ after $3 \mathrm{~min}$ incubation at room temperature. The antioxidant capacity of the extracts was calculated using the formula $\left[1-\left(\mathrm{A}_{\text {sample }} / \mathrm{A}_{\text {control }}\right)\right] \times 100$, where $\mathrm{A}_{\text {sample }}$ is the absorbance of the extracts or standards mixed with ABTS and $\mathrm{A}_{\text {control }}$ is the absorbance of the DW mixed with ABTS. The result was expressed as Trolox Equivalent Antioxidant Capacity (TEAC).

\section{Determination of hydroxyl radical scavenging assay}

The hydroxyl radical scavenging activity was performed by the method from Omwamba et al. [26] with a slight modification. Briefly, $90 \mu \mathrm{l}$ of extracts or standard solution diluted with DMSO was mixed with $45 \mu \mathrm{l}$ of $8 \mathrm{mM} \mathrm{FeSO}_{4} \cdot 7 \mathrm{H}_{2} \mathrm{O}, 63 \mu \mathrm{l}$ of $5.7 \mathrm{mM}$ salicylic acid, and $72 \mu \mathrm{l}$ of $6 \mathrm{mM} \mathrm{H}_{2} \mathrm{O}_{2}$. The reaction plate was kept in $37{ }^{\circ} \mathrm{C}$ for $30 \mathrm{~min}$, and then absorbance was measured at $562 \mathrm{~nm}$. The scavenging activity was calculated using the formula: \% OH-scavenging activity $=\left[1-\left(\mathrm{A}_{\text {sample }}-\mathrm{A}_{\text {sample blank }} / \mathrm{A}_{\text {control }}\right.\right.$ $\left.\left.\mathrm{A}_{\text {control blank }}\right)\right] \times 100$, where, $\left(\mathrm{A}_{\text {sample }}-\mathrm{A}_{\text {sample blank }}\right)$ is the difference in the absorbance of the extracts or standards (with or without salicylic acid) and $\left(\mathrm{A}_{\text {control }}-\mathrm{A}_{\text {control blank }}\right)$ is the difference in the absorbance of DMSO (with or without salicylic acid).

\section{Determination of $\alpha$-amylase inhibitory activity}

The $\alpha$-amylase inhibitory activity of the extracts was determined following the method of Ranilla et al. [27] with a minor modification. Briefly, a total of $250 \mu \mathrm{l}$ of the sample and $125 \mu \mathrm{l}$ of $0.02 \mathrm{M}$ sodium phosphate buffer ( $\mathrm{pH} 6.9$ with $6 \mathrm{mM} \mathrm{NaCl}$ ) containing $\alpha$-amylase solution $(0.5 \mathrm{mg} / \mathrm{ml})$ was incubated at $25{ }^{\circ} \mathrm{C}$ for $10 \mathrm{~min}$. After pre incubation, $250 \mu \mathrm{l}$ of $1 \%$ starch solution in $0.02 \mathrm{M}$ sodium phosphate buffer $(\mathrm{pH} 6.9$ with $6 \mathrm{mM} \mathrm{NaCl}$ ) was added to each tube at timed intervals. The reaction mixtures were then incubated at $25^{\circ} \mathrm{C}$ for $10 \mathrm{~min}$. The reaction was stopped with $0.5 \mathrm{ml}$ of dinitrosalicylic acid color reagent. The test tubes were then incubated in a boiling water bath for $5 \mathrm{~min}$ and cooled to room temperature. The reaction mixture was then diluted after adding $5 \mathrm{ml}$ of distilled water, and absorbance was measured at $540 \mathrm{~nm}$. The $\alpha$-amylase inhibitory activity was calculated using the formula: $\%$ inhibition $=(1$ $\left.\mathrm{A}_{\text {sample }} / \mathrm{A}_{\text {control }}\right) \times 100$, where $\mathrm{A}_{\text {sample }}$ and $\mathrm{A}_{\text {control }}$ were defined as absorbance of the sample and the control, respectively.

\section{Determination of $\alpha$-glucosidase inhibitory activity}

The $\alpha$-glucosidase inhibitory activity of the extracts was determined following the method of Apostolidis and Lee [28] with a minor modification. Briefly, a mixture of $50 \mu \mathrm{l}$ of sample and $100 \mu \mathrm{l}$ of $0.1 \mathrm{M}$ phosphate buffer ( $\mathrm{pH}$ 6.9) containing $\alpha$-glucosidase solution ( $1 \mathrm{U} / \mathrm{ml}$ ) was incubated in 96 well 
plates at $25{ }^{\circ} \mathrm{C}$ for $10 \mathrm{~min}$. After preincubation, $50 \mu \mathrm{l}$ of $5 \mathrm{mM}$ pNPG solution in $0.1 \mathrm{M}$ phosphate buffer ( $\mathrm{pH}$ 6.9) was added to each well at timed intervals. The reaction mixtures were incubated at $25{ }^{\circ} \mathrm{C}$ for 5 min. Before and after incubation, absorbance was recorded at $405 \mathrm{~nm}$ by a microplate reader. The $\alpha$ glucosidase inhibitory activity was expressed as $\mathrm{EC}_{50}$ and was calculated using the formula: \% inhibition $=\left(1-\mathrm{A}_{\text {sample }} / \mathrm{A}_{\text {control }}\right) \times 100$, where $\mathrm{A}_{\text {sample }}$ and $\mathrm{A}_{\text {control }}$ were defined as absorbance of the sample and the control, respectively.

\section{Animal studies}

Male IRC mice $(\mathrm{n}=48), 16$ weeks of age, were divided into 8 groups with 6 animals in each group. Group I (control) consisted of animals fed with commercial chow. Group II was fed with a high-fat control diet containing $60 \%(\mathrm{w} / \mathrm{w})$ commercial chow, $12 \%(\mathrm{w} / \mathrm{w})$ lard oil, $12 \%(\mathrm{w} / \mathrm{w})$ sucrose, $8 \%$ $(\mathrm{w} / \mathrm{w})$ egg yolk powder, $6 \%(\mathrm{w} / \mathrm{w})$ peanuts powder, and $1 \%(\mathrm{w} / \mathrm{w})$ milk powder [29]. Group III was fed with a high-fat diet plus $250 \mathrm{mg} / \mathrm{kg}$ body weight $(\mathrm{kgBW})$ of green tea extract (GT). Group IV was fed with a high-fat diet plus $500 \mathrm{mg} / \mathrm{kgBW}$ of GT. Group V was fed with a high-fat diet plus $250 \mathrm{mg} / \mathrm{kgBW}$ of $G$. atroviridis (GN). Group VI was fed with a high-fat diet plus $500 \mathrm{mg} / \mathrm{kgBW}$ of GN. Group VII was fed with a high-fat diet plus GT $250 \mathrm{mg} / \mathrm{kgBW}$ combined with GN $250 \mathrm{mg} / \mathrm{kgBW}$. Finally, Group VIII was fed with a high-fat diet plus Simvastatin $50 \mathrm{mg} / \mathrm{kgBW}$. The animals were housed in cages maintained under standard conditions (temperature $24{ }^{\circ} \mathrm{C}$, light/darkness cycles of $12 \mathrm{~h}$ ) with free access to food and water. The extract was forced fed with a gastric lavage. The experiment was approved by the Animal Ethical Committee of Walailak University (WU). The mice were maintained on these diets for another 8 weeks. Body weight and food intake were monitored once a week. After 2 months of the diet, the animals were made to fast from food overnight in preparation for plasma and tissue collection. The animals were weighed and anesthetized with a lethal dose of pentobarbital at $65 \mathrm{mg} / \mathrm{kg}$ body weight, and the thoracic abdominal cavity was opened. Blood was collected by cardiac puncture, and plasma was separated by centrifugation at $3000 \mathrm{rpm}$ for $10 \mathrm{~min}$. Plasma was collected and kept in a refrigerator at $-20{ }^{\circ} \mathrm{C}$ until used. The liver of each animal was perfused with $10 \%(\mathrm{v} / \mathrm{v})$ cold phosphate buffer saline (PBS, $\mathrm{pH} 7.4)$ and stored at $-80{ }^{\circ} \mathrm{C}$ for cryosection and hematoxylin and eosin (H\& E) staining analysis.

\section{Blood analysis}

The plasma levels of glucose (FBS), aspartate aminotransferase (AST), alanine aminotransferase (ALT), blood urea nitrogen (BUN), total cholesterol, high-density lipoproteins (HDL), and triglyceride (TG) were determined by an automated analyzer (Konelab 20i, Thermo Fisher Scientific). Plasma lowdensity lipoprotein (LDL) cholesterol was calculated by the formula of Friedewald et al. [30], and the atherogenic index was calculated from Log (TG/HDL-C) [31].

\section{Determination of lipid peroxidation marker}

The malondialdehyde (MDA) levels of plasma and liver tissue were measured as a lipid peroxidation marker according to a previously described method [32]. Lipid peroxidation (MDA) was quantified by measuring the formation of thiobarbituric acid reactive substances (MDA-TBA). Briefly, $150 \mu \mathrm{l}$ of each sample was added to $25 \mu \mathrm{l} 0.2 \%$ BHT and $600 \mu 15 \%$ aqueous. The mixture was centrifuged at $4,000 \mathrm{~g}$ for $15 \mathrm{~min}$ at $4{ }^{\circ} \mathrm{C} .300 \mu \mathrm{l}$ of the deproteinized supernatant was transferred in a 2 $\mathrm{ml}$ screw cap test tube and added with $600 \mu \mathrm{l}$ of TBA $(0.375 \%$ in $0.25 \mathrm{M} \mathrm{HCl})$. Samples were then heated at $100{ }^{\circ} \mathrm{C}$ for $15 \mathrm{~min}$ in boiling water. After cooling, sample absorbance was determined spectrophotometrically at $535 \mathrm{~nm}$ and compared to standard $\operatorname{MDA}$ (1, 1, 3, 3-tetramethoxypropane) solutions.

\section{Liver histopathology}

Livers were embedded on cryosection blocks, cut into 5-micron sections, and stained with hematoxylin and eosin. Mounting medium and cover slips were placed on the slides, and then left to dry overnight. A diagnosis of fatty liver was made based on the presence of macro or micro vesicular fat in $5 \%$ of the hepatocytes in a given slide. 


\section{Statistical analysis}

Results are shown as mean \pm SEM. Significant differences among the groups were evaluated using 1-way ANOVA, and the differences between the means were assessed using Duncan's multiple-range test. A Mann-Whitney nonparametric test was used for comparing the scores in the histopathological analysis between the control and supplementation groups. Statistical analyses with $p$-value smaller than 0.05 were considered significant.

\section{Results and discussion}

In recent years, the number of the world's population with obesity that has led to diseases including diabetes mellitus, hypertension, hyperlipidemia, cardiovascular diseases, non-alcoholic fatty liver diseases, and cancers has increased worldwide. It has been reported in many countries that consuming lipid-lowering drugs, including statin, have led to liver and muscle damage $[33,34]$. Therefore, antiobesity agents from natural products have been used instead of using drugs excessively [35]. In this study, we investigated the anti-glycemic, anti-hyperlipidemic, and anti-atherosclerosis properties of Garcinia (Garcinia atroviridis) and green tea (Camellia sinensis) extracts in high-fat diet mice. The present study suggested that these 2 herbs are potential candidates as anti-obesity medicinal plants. As we know from many studies on high phenolic plants prevent obesity has been reported worldwide [36,37]. In this study, green tea and Garcinia were obtained from the aqueous extract of dried green tea leaves and dried Garcinia fruits. We reported the total phenolic content of green tea and Garcinia as 252.44 and 5.42 $\mathrm{mgGAE} / \mathrm{g} \mathrm{dw}$, respectively, which was determined by the Folin-Ciocalteu method (Table 1).

Table 1 The Antioxidant Properties of Extracts.

\begin{tabular}{|c|c|c|c|c|}
\hline Extracts & $\begin{array}{c}\text { Phenolic content } \\
\text { GAE } \\
\text { (mg/g extract) }\end{array}$ & $\begin{array}{c}\text { DPPH scavenging } \\
\text { SC }_{50} \\
(\mu \mathrm{g} / \mathrm{mL})\end{array}$ & $\begin{array}{c}\text { ABTS scavenging } \\
\text { TEAC } \\
\text { (mg/g extract) }\end{array}$ & $\begin{array}{c}\text { Hydroxyl radical } \\
\text { scavenging } \\
\mathrm{SC}_{50} \\
(\mu \mathrm{g} / \mathrm{mL})\end{array}$ \\
\hline Green tea & $252.44 \pm 38.66$ & $75.33 \pm 5.77$ & $669.71 \pm 37.29$ & $1049.09 \pm 98.54$ \\
\hline Garcinia & $5.42 \pm 0.67$ & $4404.96 \pm 86.60$ & $2.23 \pm 0.15$ & $902.56 \pm 37.84$ \\
\hline
\end{tabular}

Data of mean \pm SEM of 3 independent experiments. GAE, Gallic Acid Equivalent; TEAC, Trolox Equivalent Antioxidant Capacity; $\mathrm{SC}_{50}, 50 \%$ of Scavenging Free Radical.

The results disclosed the same range of total phenolic content as previous reports [38,39]. The radical scavenging abilities of the 2 extracts were performed by the ABTS and DPPH method. However, ABTS assay measures the abilities of extracts to scavenge free radicals that are generated in the aqueous phase. In contrast, DPPH is a stable, synthetic radical from organic nitrogen radicals [40] that are measured from the ability of extracts to scavenge radicals. The results of the ABTS radical scavenging assay revealed that the antioxidant activity of green tea was $669.71 \mathrm{mg}$ TEAC/g dry weight and Garcinia was $2.23 \mathrm{mg} \mathrm{TEAC} / \mathrm{g}$ dry weight, indicating that the ability to scavenge the radicals in the aqueous phase of green tea was greater than Garcinia. In the same way, the results of DPPH were expressed as $50 \%$ scavenging capacity $\left(\mathrm{SC}_{50}\right)$ and showed that the ability of green tea was greater than Garcinia (75.33 and $4404.96 \mu \mathrm{g} / \mathrm{mL}$, respectively). However, there were other potent reactive oxygen species in the biological system called hydroxyl radicals, which are highly reactive and short-lived radicals from hydroxide ion $(\mathrm{OH}-)$ and have highly destructive effects on cellular components which can cause peroxidation of lipids and attack cellular molecules such as RNA, proteins, and DNA. In our study, hydroxyl radicals were generated by the Fenton reaction [41], and the reaction was measured by the Griess Illosvoy reaction [42]. The result indicated that the ability of Garcinia to scavenge the hydroxyl radicals was greater than green 
tea. These results follow the previous reports from preceding studies that Garcinia, which is rich in HCA, can attribute to the ability of hydroxyl radical scavenging, stronger than green tea catechin [43].

In the animal study, the effects of green tea and Garcinia treatment on high-fat diet mice were determined. After the induction of obesity in mice and treatment for 8 weeks, there was a significant increase in body weight of the mice in the high-fat diet grou $p$ when compared to the normal diet group and the extracts-treated groups after 2 weeks $(p<0.05)$. Moreover, the high-fat diet group had a significant increase $(1.3$ - fold) when compared to the treated group and statin group $(p<0.05)$. However, there was no significant difference in body weight among the treated and statin group $(p<0.05)$ (Figure 1). In the experiments, no significant differences were observed in the food intake between the control diet-fed mice and the high-fat diet mice (data not shown). These observations indicated that extracts did not cause an anorectic effect responsible for the prevention or reduction of the high-fat diet induced in body weight and adipose tissue mass.

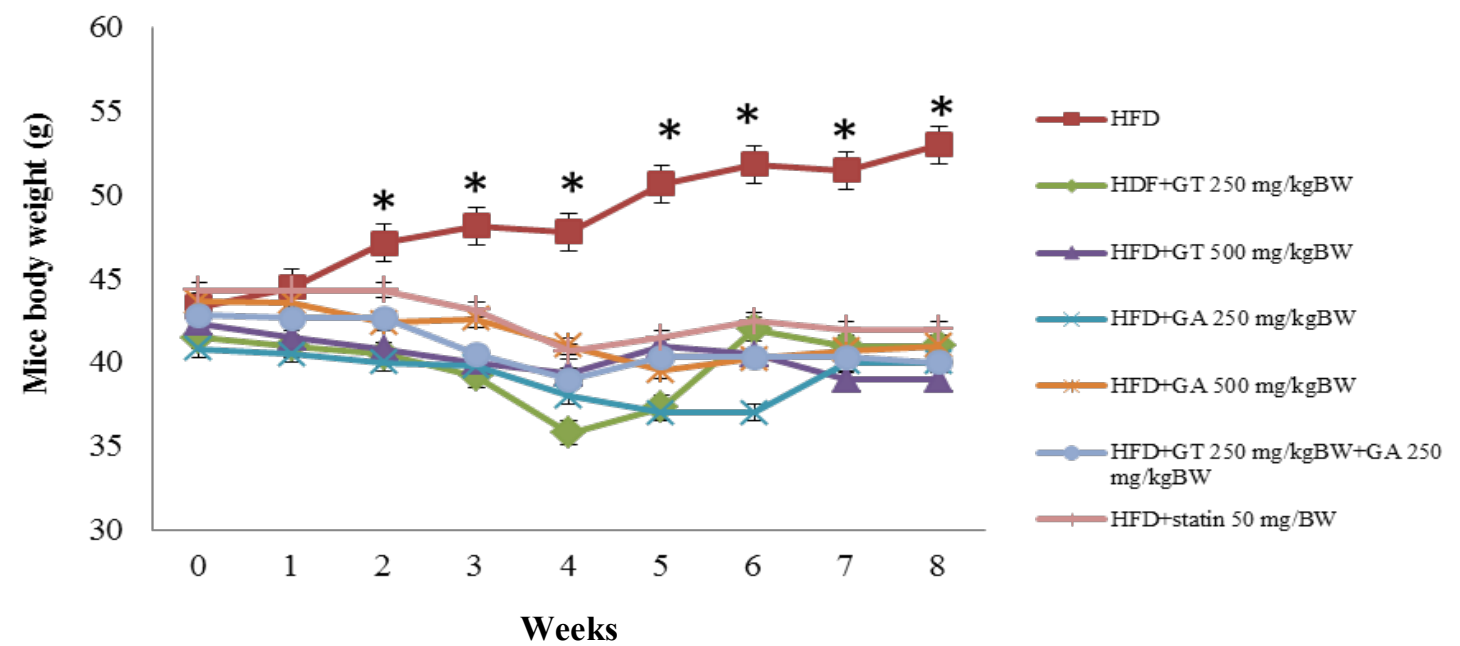

Figure 1 Body Weight of Mice Fed with High-Fat Diet and Co-Treated with Green Tea and Garcinia for 8 weeks.

The effects of green tea and Garcinia extracts on the development of diet-induced obesity in IRC mice were examined. The results showed that dietary green tea and Garcinia extracts successfully reduced blood cholesterol, triglyceride, LDL levels, and glucose levels. Meanwhile, the same extracts improved HDL levels (Table 2). These results confirm that green tea and Garcinia plays a critical role in the reduction of atherosclerosis index. In addition, it has been reported that consuming green tea catechins, including EGCG, markedly reduced blood sugar and body weight [44,45]. It has also been previously reported that HCA in Garcinia could reduce serum triglyceride and cholesterol, resulting in the inhibition of lipogenesis via blocking acetyl-CoA, which is the required binding molecule for fatty acid and cholesterol biosynthesis $[46,47]$. 
Table 2 The Effects of Green Tea and Garcinia Extracts on Blood Levels of Cholesterol, Triglyceride, LDL, HDL, Glucose, and Atherosclerosis Index (AI) in High-Fat Diet (HFD) Mice Fed for 8 Weeks.

\begin{tabular}{lcccccc}
\hline \multicolumn{1}{c}{ Treatment } & $\begin{array}{c}\text { Cholesterol } \\
(\mathbf{m g} / \mathbf{d l})\end{array}$ & $\begin{array}{c}\text { Triglycerides } \\
(\mathbf{m g} / \mathbf{d l})\end{array}$ & $\begin{array}{c}\text { LDL } \\
(\mathbf{m g} / \mathbf{d l})\end{array}$ & $\begin{array}{c}\text { HDL } \\
(\mathbf{m g} / \mathbf{d l})\end{array}$ & $\begin{array}{c}\text { Glucose } \\
(\mathbf{m g} / \mathbf{d l})\end{array}$ & $\begin{array}{c}\text { Atherosclero } \\
\text { sis index }\end{array}$ \\
\hline Normal Control & $110.57 \pm 5.90$ & $53.71 \pm 4.20$ & $41.38 \pm 4.80$ & $69.21 \pm 3.60$ & $163.15 \pm 9.80$ & $0.63 \pm 0.04$ \\
HFD & $147.32 \pm 12.80^{\mathrm{a}}$ & $73.54 \pm 8.60^{\mathrm{a}}$ & $58.00 \pm 6.90^{\mathrm{a}}$ & $63.50 \pm 3.10^{\mathrm{a}}$ & $191.25 \pm 9.50^{\mathrm{a}}$ & $0.91 \pm 0.09^{\mathrm{a}}$ \\
HFD + GT 250 mg/kgBW & $126.41 \pm 3.50^{\mathrm{b}}$ & $30.86 \pm 13.40^{\mathrm{b}}$ & $55.30 \pm 6.00$ & $62.59 \pm 3.90$ & $196.76 \pm 5.20$ & $0.87 \pm 0.02$ \\
HFD + GT 500 mg/kgBW & $139.62 \pm 13.20$ & $52.73 \pm 10.20^{\mathrm{b}}$ & $56.84 \pm 2.70$ & $68.64 \pm 6.90^{\mathrm{b}}$ & $165.83 \pm 10.20^{\mathrm{b}}$ & $0.83 \pm 0.03^{\mathrm{b}}$ \\
HFD + GA 250 mg/kgBW & $137.85 \pm 8.30$ & $43.41 \pm 13.50^{\mathrm{b}}$ & $54.40 \pm 6.00$ & $66.51 \pm 3.90$ & $141.51 \pm 5.70^{\mathrm{b}}$ & $0.81 \pm 0.02^{\mathrm{b}}$ \\
HFD + GA 500 mg/kgBW & $106.57 \pm 7.40^{\mathrm{b}}$ & $52.67 \pm 9.10^{\mathrm{b}}$ & $44.05 \pm 5.60^{\mathrm{b}}$ & $69.10 \pm 5.60^{\mathrm{b}}$ & $171.69 \pm 6.90^{\mathrm{b}}$ & $0.76 \pm 0.13^{\mathrm{b}}$ \\
HFD + GT 250 mg/kgBW & $125.68 \pm 7.10^{\mathrm{b}}$ & $48.19 \pm 7.80^{\mathrm{b}}$ & $47.94 \pm 7.10^{\mathrm{b}}$ & $67.25 \pm 9.40^{\mathrm{b}}$ & $124.73 \pm 25.10^{\mathrm{b}}$ & $0.61 \pm 0.06^{\mathrm{b}}$ \\
plus GA 250 mg/kgBW & $128.49 \pm 10.20^{\mathrm{b}}$ & $59.29 \pm 5.90^{\mathrm{b}}$ & $46.28 \pm 4.90^{\mathrm{b}}$ & $72.07 \pm 11.90^{\mathrm{b}}$ & $178.93 \pm 7.40$ & $0.60 \pm 0.05^{\mathrm{b}}$ \\
HFD + Statin 50 mg/kgBW & 12.49 &
\end{tabular}

Data of mean \pm SEM of 3 independent experiments. HDF, high-fat diet; GT, green tea extract; GA, Garcinia atroviridis extract. ${ }^{\mathrm{a}} p<0.05$; HFD mice compared to control normal diet group. ${ }^{\mathrm{b}} p<0.05$; HFD-treated group with extracts compared to HFD-treated group in the same column.

The extracts of green tea and Garcinia were orally administered daily for 8 weeks, and the doses were in the non-hepatotoxic range for mice which showed no significant differences in the plasma activities of AST, ALT, and BUN when compared to the normal control groups. Obese mice fed with HFD showed a significant increase in AST and ALT liver enzyme activities $(p<0.05)$. Treatment with these extracts improved liver tissue damage indicated by reduced liver enzyme activities. Moreover, the doses of these extracts showed a potently reduced MDA, the lipid peroxidation maker, in blood and liver tissues $(p<0.05)$ (Table 3).

The inhibitory effects of the extracts and their $\mathrm{EC}_{50}$ values on $\alpha$-amylase and $\alpha$-glucosidase are presented in Table 4. It can be observed that both of the extracts showed inhibition on $\alpha$-amylase and $\alpha$ glucosidase. The concentration of the extracts was at $500 \mu \mathrm{g} / \mathrm{mL}$ to examine the $\alpha$-amylase and $\alpha$ glucosidase inhibition. The result of $\alpha$-amylase inhibition showed that Garcinia had a stronger ability than green tea to inhibit, showing the reduction of enzyme activity from $36.84 \mathrm{U} / \mathrm{L}$ (control) to $22.00 \mathrm{U} / \mathrm{L}$ and $25.59 \mathrm{U} / \mathrm{L}$ by 40.12 and $30.06 \%$, respectively. The values of $\mathrm{EC}_{50}$ were 618.51 and $810.90 \mu \mathrm{g} / \mathrm{mL}$ for Garcinia and green tea, respectively. In the same way, the result of $\alpha$-glucosidase inhibition showed that Garcinia also had a stronger ability than green tea to inhibit, showing the reduction of enzyme activity from $38.38 \mathrm{U} / \mathrm{L}$ (control) to $29.68 \mathrm{U} / \mathrm{L}$ and $31.73 \mathrm{U} / \mathrm{L}$ by 22.58 and $17.14 \%$, respectively. The values of $\mathrm{EC}_{50}$ were 1096.49 and $1453.49 \mu \mathrm{g} / \mathrm{mL}$ for Garcinia and green tea, respectively. Moreover, we observed that $\alpha$-amylase and $\alpha$-glucosidase inhibitory activities of green tea and Garcinia showed moderate inhibition of $\alpha$-amylase and $\alpha$-glucosidase, which correlated to the reduction of blood sugar and triglyceride in mice treated with a high-fat diet (Table 2). According to a previous study, it has been reported that the HCA isomer $(2 \mathrm{~s}, 3 \mathrm{r}$ ) inhibits $\alpha$-amylase activity and $\alpha$-glucosidase activity [48], leading to the reduction of carbohydrate metabolism and absorption with significant reduction in blood glucose in diabetic patients [49]. In addition, it has been reported that the EGCG in green tea is a potent $\alpha$-amylase and $\alpha$-glucosidase inhibitor [50,51]. 
Table 3 The Effects of Green Tea and Garcinia Extracts on Liver Enzyme, Kidney Function Marker (BUN), and Lipid Peroxidation Product (MDA) in Blood and Liver Tissues.

\begin{tabular}{|c|c|c|c|c|c|}
\hline Group & $\begin{array}{l}\text { AST } \\
(\mathbf{U} / \mathbf{L})\end{array}$ & $\begin{array}{l}\text { ALT } \\
\text { (U/L) }\end{array}$ & $\begin{array}{c}\text { BUN } \\
(\mathrm{mg} / \mathrm{dL})\end{array}$ & $\begin{array}{c}\text { MDA } \\
(\mathrm{nM} / \mathrm{ml})\end{array}$ & $\begin{array}{c}\text { MDA } \\
\text { (nM/g potein) }\end{array}$ \\
\hline Normal Control & $124.0 \pm 8.4$ & $22.0 \pm 5.4$ & $25.0 \pm 0.9$ & $1.5 \pm 0.2$ & $24.6 \pm 3.1$ \\
\hline HFD control & $172.0 \pm 23.8^{\mathrm{a}}$ & $36.0 \pm 2.8^{\mathrm{a}}$ & $26.0 \pm 1.4$ & $6.5 \pm 0.8^{\mathrm{a}}$ & $172.9 \pm 13.6^{\mathrm{a}}$ \\
\hline $\mathrm{HFD}+\mathrm{GT} 250 \mathrm{mg} / \mathrm{kgBW}$ & $77.0 \pm 33.8^{\mathrm{a}, \mathrm{b}}$ & $18.0 \pm 2.8$ & $24.0 \pm 1.4$ & $2.7 \pm 0.8^{\mathrm{b}}$ & $77.1 \pm 6.4^{\mathrm{b}}$ \\
\hline $\mathrm{HFD}+\mathrm{GT} 500 \mathrm{mg} / \mathrm{kgBW}$ & $163.0 \pm 34.8$ & $40.0 \pm 6.6$ & $24 \pm 1.3$ & $1.6 \pm 0.5^{\mathrm{b}}$ & $28.7 \pm 9.5^{\mathrm{b}}$ \\
\hline $\mathrm{HFD}+\mathrm{GA} 250 \mathrm{mg} / \mathrm{kgBW}$ & $98.0 \pm 33.8^{\mathrm{a}, \mathrm{b}}$ & $26.0 \pm 2.3$ & $26.0 \pm 1.0$ & $2.8 \pm 0.7^{\mathrm{b}}$ & $65.4 \pm 9.2^{\mathrm{b}}$ \\
\hline $\mathrm{HFD}+\mathrm{GA} 500 \mathrm{mg} / \mathrm{kgBW}$ & $112.0 \pm 27.2$ & $31.0 \pm 4.6$ & $20.0 \pm 1.9$ & $2.1 \pm 0.6^{\mathrm{b}}$ & $45.3 \pm 6.8^{b}$ \\
\hline $\begin{array}{l}\mathrm{HFD}+\mathrm{GT} 250 \mathrm{mg} / \mathrm{kgBW}+ \\
\text { GA } 250 \mathrm{mg} / \mathrm{kgBW}\end{array}$ & $155.0 \pm 27.8$ & $33.0 \pm 3.6$ & $23.0 \pm 1.6$ & $1.9 \pm 0.8^{\mathrm{b}}$ & $32.6 \pm 8.3^{\mathrm{b}}$ \\
\hline $\mathrm{HFD}+$ Statin $50 \mathrm{mg} / \mathrm{kgBW}$ & $156.0 \pm 27.9$ & $25.0 \pm 1.1$ & $24.0 \pm 1.0$ & $2.85 \pm 0.6^{\mathrm{b}}$ & $52.8 \pm 6.9^{\mathrm{b}}$ \\
\hline
\end{tabular}

Table 4 The Inhibitory Effect of Green Tea and Garcinia Extracts on Pancreatic Enzyme $\alpha$-Amylase and $\alpha$-Glucosidase In Vitro.

\begin{tabular}{|c|c|c|c|c|c|c|}
\hline \multirow[b]{2}{*}{ Extracts } & \multicolumn{3}{|c|}{$\alpha$-Amylase } & \multicolumn{3}{|c|}{$\alpha$-Glucosidase } \\
\hline & $\mathbf{U} / \mathbf{L}$ & $\begin{array}{l}\text { \% inhibition } \\
(500 \mu \mathrm{g} / \mathrm{ml})\end{array}$ & $\begin{array}{c}\mathbf{E C}_{50} \\
(\mu \mathrm{g} / \mathrm{mL})\end{array}$ & $\mathbf{U} / \mathbf{L}$ & $\begin{array}{c}\% \\
\text { inhibition } \\
(500 \mu \mathrm{g} / \mathrm{ml})\end{array}$ & $\begin{array}{c}\mathbf{E C}_{50} \\
(\mu \mathrm{g} / \mathbf{m L})\end{array}$ \\
\hline Control & $36.84 \pm 2.66$ & - & - & $38.38 \pm 1.54$ & - & - \\
\hline Green tea & $25.59 \pm 1.77^{\mathrm{a}}$ & 30.06 & 810.90 & $31.73 \pm 1.77^{\mathrm{a}}$ & 17.14 & $1,453.49$ \\
\hline Garcinia & $22.00 \pm 0.09^{\mathrm{a}, \mathrm{b}}$ & 40.12 & 618.51 & $29.68 \pm 0.09^{\mathrm{a}, \mathrm{b}}$ & 22.58 & $1,096.49$ \\
\hline
\end{tabular}

H\&E staining of liver tissue indicated the presence of high-fat diet-induced hepatic steatosis. The number of adipocyte significantly increased in the high-fat diet group when compared to the normal control group. The adipocyte size of the high-fat diet group was significantly bigger than the normal control group. The number of adipocyte was reduced in all green tea and Garcinia extracts-treated groups when compared to the high-fat diet control group. For all treated groups, their adipocyte sizes were significantly smaller than the high-fat diet group: their numbers of fat cells were significantly less than the high-fat diet group (Figure 2). 


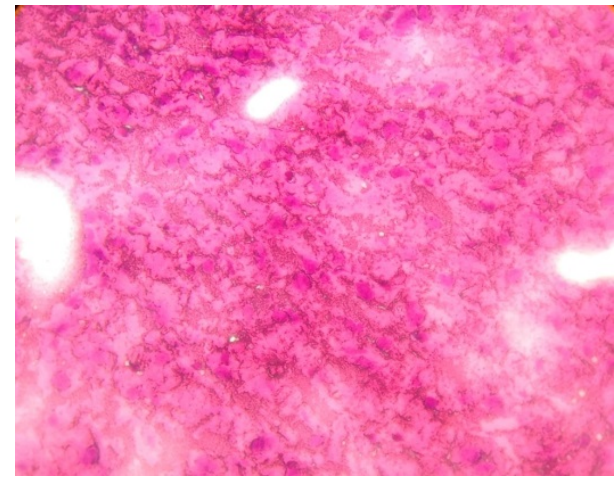

A. Normal control

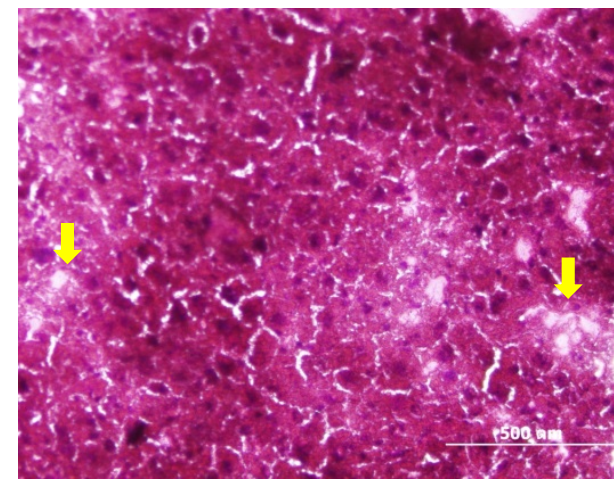

C. HFD + Green Tea $250 \mathrm{mg} / \mathrm{kgBW}$

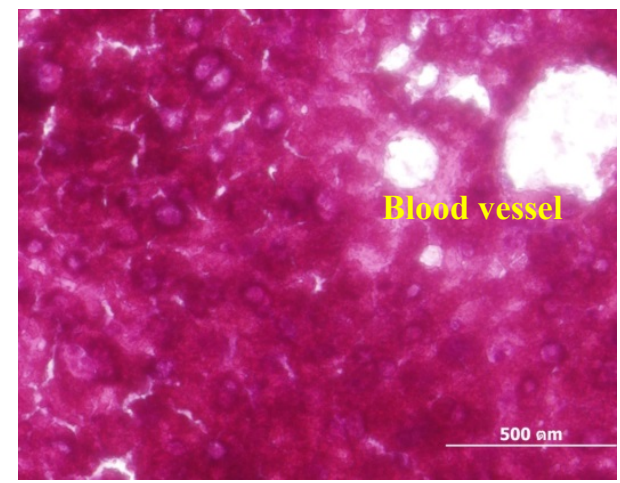

E. HFD + Green Tea 500 mg/kgBW

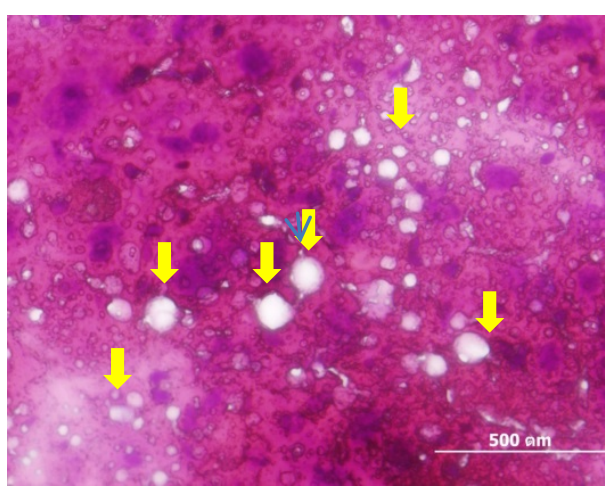

B. HFD control

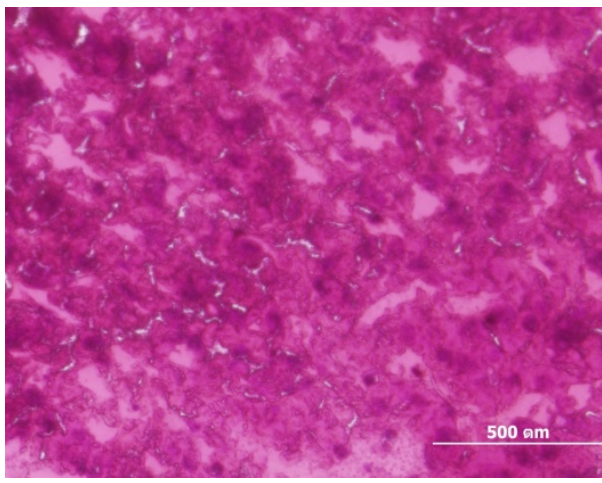

D. HFD + Garcinia $250 \mathrm{mg} / \mathrm{kgBW}$

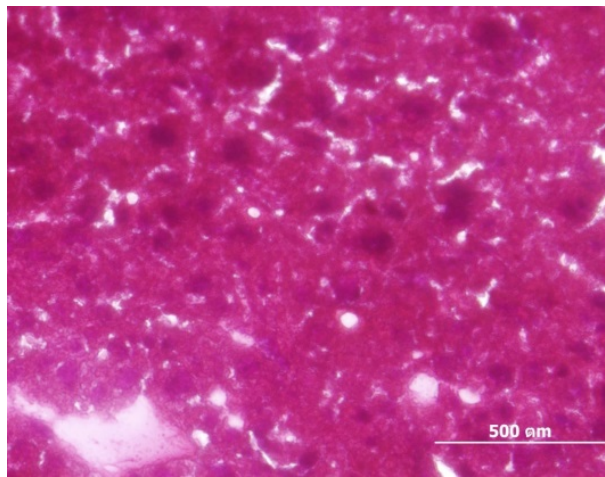

F. HFD + Garcinia $500 \mathrm{mg} / \mathrm{kgBW}$ 


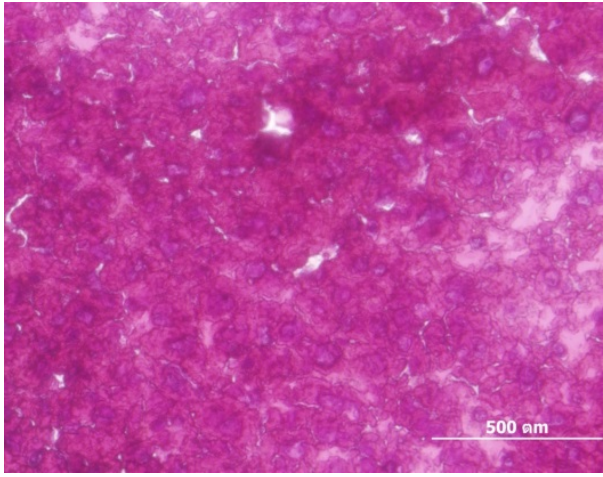

G. HFD + Green Tea 250 plus Garcinia $250 \mathrm{mg} / \mathrm{kgBW}$

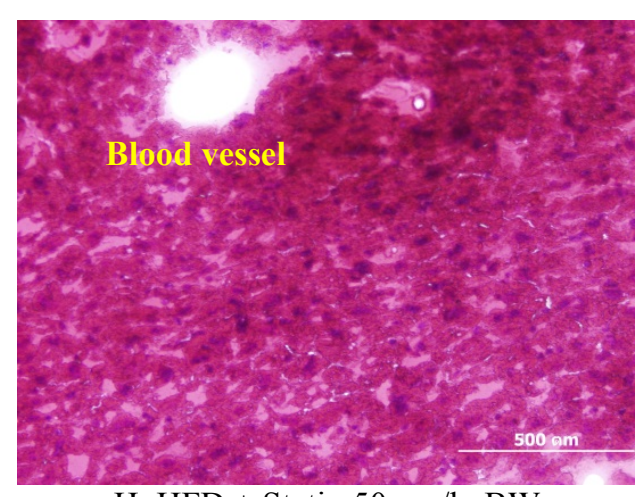

H. HFD + Statin $50 \mathrm{mg} / \mathrm{kgBW}$

Figure 2 Liver Histopathology Effects of Green Tea and Garcinia Extracts in High-Fat Fed Mice for 8 weeks.

A. Mice were fed with normal chow, B, Mice were fed with HFD, C. Mice were fed with HFD and co-treatment with green tea extract $250 \mathrm{mg} / \mathrm{kgBW}$, D. Mice were fed with HFD and co-treatment with Garcinia extract $250 \mathrm{mg} / \mathrm{kgBW}$, E. Mice were fed with HFD and co-treatment with green tea extract 500 $\mathrm{mg} / \mathrm{kgBW}, \mathrm{F}$. Mice were fed with HFD and co-treatment with Garcinia extract $500 \mathrm{mg} / \mathrm{kgBW}$, G. Mice were fed with HFD and co-treatment with green tea extract 250 plus Garcinia $250 \mathrm{mg} / \mathrm{kgBW}$, H. Mice were fed with HFD and co-treatment with statin $50 \mathrm{mg} / \mathrm{kgBW}$. The arrow indicates the fat cell droplets.

Furthermore, green tea and Garcinia extracts could reduce fat cells in liver tissue as shown in Figure 2, consistent with similar decreases in cholesterol, LDL, and triglyceride (Table 2). The potential mechanism may involve the inhibition of intestinal lipid absorption by green tea, particularly EGCG [52]. Thus, it is probable that the decreased hepatic lipid accumulation may be associated with the decreased absorption of lipids at the intestinal level. In addition, HCA in Garcinia is known to inhibit the lipogenesis catalyzed by ATP citrate-lyase in the liver and peripheral tissues, as reported previously [53]. Our results also confirmed that both green tea and Garcinia showed potency in free radical scavenging and a reduction of MDA in blood and liver tissues. Taken together, these results suggest that the green tea and Garcinia extracts may have a beneficial role in improving hepatosteatosis induced by HFD, although the in-depth mechanism for the experimental model of this study needs to be clarified.

\section{Conclusions}

In conclusion, this study has demonstrated the effectiveness of green tea and Garcinia in modulating the plasma lipid profile, hepatic lipid accumulation and blood glucose level with non-toxic to the body. The analysis results suggest that the use of plant extracts, both of Garcinia and green tea extracts, are viable alternatives to pharmaceutical inhibitors of dyslipidemia and hyperglycemia, thus exert the reduction of atherosclerosis risk. Therefore, this investigation has revealed the potential of green tea and Garcinia extracts to be used as a natural oral dietary supplement with both hypoglycemic and hypolipidemic effects. More clinical trials are needed to demonstrate the efficacy of these extracts in human volunteers to lower postprandial hyperglycemia and hyperlipidemia. Moreover, efficacy of provided evidence of this functional food formula may be developed as a new potential natural product for the prevention of hyperlipidemia and obesity in future. 


\section{Acknowledgements}

This study was supported in part by the Graduate WU Research Grants and the Walailak University Grant (WU 61501), Thailand.

\section{References}

[1] L Landsberg, L Aronne, L Beilin, V Burke, LI Igel, DL Lloyd-Jones and JR Sowers, Obesity-related hypertension: Pathogenesis, cardiovascular risk, and treatment. A position paper of the obesity society and the american society of hypertension. Obesity 2013; 21, 8-24.

[2] N Ogier, M Amiot, S Georgé, M Maillot, C Mallmann, M Maraninchi, S Morange, JF Lescuyer, SL Peltier and $\mathrm{N}$ Cardinault. LDL-cholesterol-lowering effect of a dietary supplement with plant extracts in subjects with moderate hypercholesterolemia. Eur. J. Nutr. 2013; 52, 547-57.

[3] G Baskaran, S Salvamani, A Azlan, SA Ahmad, SK Yeap and MY Shukor. Hypocholesterolemic and antiatherosclerotic potential of Basella alba leaf extract in hypercholesterolemia-induced rabbits. Evid. Based Compl. Altern. Med. 2015; 2015, 7.

[4] N Chaipichit, J Krska, T Pratipanawatr and N Jarernsiripornkul. Statin adverse effects: Patients experiences and laboratory monitoring of muscle and liver injuries. Int. J. Clin. Pharm. 2015; 37, 355-64.

[5] H Graham. Green tea composition, consumption, and polyphenol chemistry. Prev. Med. 1992; 21, 334-50.

[6] K Yoshino, Y Hara, M Sano and I Tomita. Antioxidative effects of black tea theaflavins and thearubigin on lipid peroxidation of rat liver homogenates induced by tert-butyl hydroperoxide. Biol. Pharm. Bull. 1994; 17, 146-9.

[7] M Nakayama, K Suzuki, M Toda, S Okubo, Y Hara and T Shimamura. Inhibition of the infectivity of influenza virus by tea polyphenols. Antivir. Res. 1993; 21, 289-99.

[8] M Hattori, I Kusumoto, T Namba, T Ishigami and Y Hara. Effect of tea polyphenols on glucan synthesis by glucosyltransferase from Streptococcus mutans. Chem. Pharm. Bull. 1990; 38, 717-20.

[9] S Katiyar and H Mukhtar. Tea in chemoprevention of cancer. Int. J. Oncol. 1996; 8, 221-38.

[10] J Henry and P Stephens-Larson. Reduction of chronic psychosocial hypertension in mice by decaffeinated tea. Hypertension 1984; 6, 437-44.

[11] H Tsuneki, M Ishizuka, M Terasawa, JB Wu, T Sasaoka and I Kimura. Effect of green tea on blood glucose levels and serum proteomic patterns in diabetic $(\mathrm{db} / \mathrm{db})$ mice and on glucose metabolism in healthy humans. BMC Pharmacol. 2004; 4, 18.

[12] P Chan, W Fong, YL Cheung, Y Huang, WK Ho and ZY Chen. Jasmine green tea epicatechins are hypolipidemic in hamsters (Mesocricetus auratus) fed a high fat diet. J. Nutr. 1999; 129, 1094-101.

[13] T Murase, A Nagasawa, J Suzuki, T Hase and I Tokimitsu. Beneficial effects of tea catechins on diet-induced obesity: Stimulation of lipid catabolism in the liver. Int. J. Obes. Relat. Metab. Disord. 2002; 26, 1459-64.

[14] L Zhang, Y Wei and J Zhang. Novel mechanisms of anticancer activities of green tea component epigallocatechin-3-gallate. Anticancer. Agents. Med. Chem. 2014; 14, 779-86.

[15] JCW Mak. Potential role of green tea catechins in various disease therapies: Progress and promise. Clin. Exp. Pharmacol. Physiol. 2012; 39, 265-73.

[16] M Mackeen, A Ali, N Lajis, K Kawazu, Z Hassan, M Amran, M Habsah, LY Mooi and SM Mohamed. Antimicrobial, antioxidant, antitumour-promoting and cytotoxic activities of different plant part extracts of Garcinia atroviridis griff. ex T. anders. J. Ethnopharmacol. 2000; 72, 395402.

[17] L Muensritharam, V Tolieng, C Chaichantipyuth, A Petsom and T Nhujak. Capillary zone electrophoresis for separation and analysis of hydroxycitric acid and hydroxycitric acid lactone: application to herbal products of Garcinia atroviridis griff. J Pharm Biomed Anal. 2008; 46, 57782. 
[18] J Watson, M Fang and J Lowenstein. Tricarballylate and hydroxycitrate: Substrate and inhibitor of ATP: Citrate oxaloacetate lyase. Arch. Biochem. Biophys. 1969; 135, 209-17.

[19] X Zu, Q Zhang, JH Liu, RX Cao, J Zhong, GH Yi, ZH Quan and G Pizzorno. ATP citrate lyase inhibitors as novel cancer therapeutic agents. Recent. Pat. Anticancer 2012; 7, 154-67.

[20] C Roongpisuthipong, R Kantawan and W Roongpisuthipong. Reduction of adipose tissue and body weight: Effect of water soluble calcium hydroxycitrate in Garcinia atroviridis on the short term treatment of obese women in Thailand. Asia. Pac. J. Clin. Nutr. 2007; 16, $25-9$.

[21] R Rao and K Sakariah. Lipid-lowering and antiobesity effect of (-)hydroxycitric acid. Nutr. Res. 1988; 8, 209-12.

[22] K Hayamizu, Y Ishii, I Kaneko, M Shen, Y Okuhara, N Shigematsu, H Tomi, M Furuse, G Yoshino and $\mathrm{H}$ Shimasaki. Effects of garcinia cambogia (hydroxycitric acid) on visceral fat accumulation: a double-blind, randomized, placebo-controlled trial. Curr. Ther. Res. Clin. Exp. 2003; 64, 551-67.

[23] V Singleton and J Rossi. Colorimetry of total phenolics with phosphomolybdic-phosphotungstic acid reagents. Am. J. Eno.l Viticult. 1965; 16, 144.

[24] M Blois. Antioxidant Determinations by the use of a stable free radical. Nature 1958; 181, 1199.

[25] R Re, N Pellegrini, A Proteggente, A Pannala, M Yang and C Rice-Evans. Antioxidant activity applying an improved ABTS radical cation decolorization assay. Free. Radic. Biol. Med. 1999; 26, 1231-7.

[26] M Omwamba, F Li, G Sun and Q Hu. Antioxidant effect of roasted barley (Hordeum vulgare L.) grain extract towards oxidative stress in Vitro and in Vivo. Food. Nutr. Sci. 2013; 4, 8.

[27] L Ranilla, Y Kwon, E Apostolidis and K Shetty. Phenolic compounds, antioxidant activity and in vitro inhibitory potential against key enzymes relevant for hyperglycemia and hypertension of commonly used medicinal plants, herbs and spices in Latin America. Bioresour. Technol. 2010; 101, 4676-89.

[28] E Apostolidis and C Lee. In vitro potential of ascophyllum nodosum phenolic antioxidant-mediated alpha-glucosidase and alpha-amylase inhibition. J. Food Sci. 2010; 75, H97-H102.

[29] C Tian, X Ye, R Zhang, J Long, W Ren, S Ding, D Liao, X Jin, H Wu, S Xu and C Ying. Green tea polyphenols reduced fat deposits in high fat-fed rats via erk1/2-PPARgamma-adiponectin pathway. PLoS One 2013; 8, e53796.

[30] W Friedewald, R Levy and DS Fredrickson. Estimation of the concentration of low-density lipoprotein cholesterol in plasma, without use of the preparative ultracentrifuge. Clin Chem. 1972; 18, 499-502.

[31] M Dobiášová and J Frohlich. The plasma parameter log (TG/HDL-C) as an atherogenic index: Correlation with lipoprotein particle size and esterification rate inapob-lipoprotein-depleted plasma (FERHDL). Clin. Biochem. 2001; 34, 583-8.

[32] J Lovrij, M Mesij, M Macan, M Koprivanac, M Kelava and V Bradamante. Measurement of malondialdehyde (MDA) level in rat plasma after simvastatin treatment using two different analytical methods. Period Biol. 2008; 110, 63-7.

[33] A Pandit, T Sachdeva and P Bafna. Drug-induced hepatotoxicity: A review. J Appl. Pharm. Sci. 2012; 2, 233-43.

[34] E Stroes, P Thompson, A Corsini, GD Vladutiu, FJ Raal, KK Ray, M Roden, E Stein, L Tokgözoğlu, BG Nordestgaard, E Bruckert, GD Backer, RM Krauss, U Laufs, RD Santos, RA Hegele, GK Hovingh, LA Leiter, F Mach, W März, CB Newman, O Wiklund, TA Jacobson, AL Catapano, MJ Chapman, HN Ginsberg and European Atherosclerosis Society Consensus Panel. Statin-associated muscle symptoms: Impact on statin therapy-european atherosclerosis society consensus panel statement on assessment, aetiology and management. Eur. Heart. J. 2015; 36, 1012-22.

[35] M Naruszewicz, I Laniewska, B Millo and M Dłuzniewski. Combination therapy of statin with flavonoids rich extract from chokeberry fruits enhanced reduction in cardiovascular risk markers in patients after myocardial infraction (MI). Atherosclerosis 2007; 194, e179-84. 
[36] $\mathrm{Y} \mathrm{Xu}, \mathrm{M}$ Zhang, $\mathrm{T} \mathrm{Wu}, \mathrm{SD}$ Dai, J Xu and $\mathrm{Z}$ Zhou. The anti-obesity effect of green tea polysaccharides, polyphenols and caffeine in rats fed with a high-fat diet. Food. Funct. 2015; 6, 296-303.

[37] D Heber, Y Zhang, J Yang, JE Ma, SM Henning and Z Li. Green tea, black tea, and Oolong tea polyphenols reduce visceral fat and inflammation in mice fed high-fat, high-sucrose obesogenic diets. J. Nutr. 2014; 144, 1385-93.

[38] EHK Ikram, K Eng, AMM Jalil, A Ismail, S Idris, A Azlan, HSM Nazri, NAM Diton and RAM Mokhtar. Antioxidant capacity and total phenolic content of Malaysian underutilized fruits. J. Food. Compos. Anal. 2009; 22, 388-93.

[39] M Rodrigues, V Neves, A Martins, AP Rauter, NR Neng, JMF Nogueira, J Varela, L Barreira and L Custódio. In vitro antioxidant and anti-inflammatory properties of limonium algarvense flowers' infusions and decoctions: A comparison with green tea (Camellia sinensis). Food. Chem. 2016; 200, $322-9$.

[40] K Lesley, G Lisa and L Manohar. Methodology for the determination of biological antioxidant capacity in vitro: A review. J. Sci. Food. Agric. 2006; 86, 2046-56.

[41] S Mandal, B Hazra, R Sarkar, S Biswas and N Mandal. Assessment of the antioxidant and reactive oxygen species scavenging activity of methanolic extract of caesalpinia crista leaf. Evid. Based Compl. Altern. Med. 2011; 2011, 11.

[42] R Patel and N Patel. In vitro antioxidant activity of coumarin compounds by DPPH, super oxide and nitric oxide free radical scavenging methods. J. Adv. Pharm. Educ. Res. 2011; 1, 52-68.

[43] F Yamaguchi, M Saito, T Ariga, Y Yoshimura and H Nakazawa. Free radical scavenging activity and antiulcer activity of garcinol from Garcinia indica fruit rind. J. Agric. Food Chem. 2000; 48, 2320-5.

[44] S Klaus, S Pültz, C Thöne-Reineke and S Wolfram. Epigallocatechin gallate attenuates diet-induced obesity in mice by decreasing energy absorption and increasing fat oxidation. Int. J. Obes. 2005; 29, 615.

[45] S Wolfram, D Raederstorff, M Preller, Y Wang, SR Teixeira, C Riegger and P Weber. Epigallocatechin gallate supplementation alleviates diabetes in rodents. J. Nutr. 2006; 136, 2512-8.

[46] A Sullivan, J Hamilton, ON Miller and VR Wheatley. Inhibition of lipogenesis in rat liver by (-)hydroxycitrate. Arch. Biochem. Biophys. 1972; 150, 183-90.

[47] AC Sullivan, J Triscari, JG Hamilton, ON Miller and VR Wheatley. Effect of (-)-hydroxycitrate upon the accumulation of lipid in the rat: I. Lipogenesis. Lipids 1974; 9, 121-8.

[48] C Hansawasdi, J Kawabata and T Kasai. Alpha-amylase inhibitors from roselle (Hibiscus sabdariffa Linn.) tea. Biosci. Biotechnol. Biochem. 2000; 64, 1041-3.

[49] T Buchholz and M Melzig. Polyphenolic compounds as pancreatic lipase inhibitors. Planta Med. $2015 ; \mathbf{8 1}, 771-83$.

[50] AS Boath, D Grussu, D Stewart and GJ McDougall. Berry polyphenols inhibit digestive enzymes: A source of potential health benefits. Food. Digestion 2012; 3, 1-7.

[51] A Dalar and I Konczak. Phenolic contents, antioxidant capacities and inhibitory activities against key metabolic syndrome relevant enzymes of herbal teas from eastern Anatolia. Ind. Crop. Prod. 2013; 44, 383-90.

[52] S Koo and S Noh. Green tea as inhibitor of the intestinal absorption of lipids: Potential mechanism for its lipid-lowering effect. J. Nutr. Biochem. 2007; 18, 179-83.

[53] AC Sullivan, M Singh, PA Srere and JP Glusker. Reactivity and inhibitor potential of hydroxycitrate isomers with citrate synthase, citrate lyase, and ATP citrate lyase. J. Biol. Chem. 1977; 252, 7583-90. 